\title{
Hodnotenie rýchlostno-silových schopností profesionálnych hokejistov $v$ trojročnom časovom intervale
}

\section{The assessment of speed and strength in professional hockey players over a three-year time period}

\author{
Marek Kokinda, Martin Jesenský, Milan Turek \\ Fakulta športu, Prešovská univerzita v Prešove, Slovenská republika
}

\begin{abstract}
Abstrakt
Problematiku rýchlostno-silových schopnostíje možné označit'za determinujúcu pre úspešnost' v ladovom hokeji. Jej rozvoju sa venuje zvýšená pozornost hlavne v letnom prípravnom období. Po jeho ukončení, hráči absolvovali diagnostiku zameranú na hodnotenie telesnej kompozície, silových schopností a analýzu anaeróbnych alaktátových schopností realizovanú Wingate testom. Referenčnú skupinu tvorili 11 hokejisti seniorskej kategórie pôsobiaci v zahraničnej a slovenskej hokejovej lige. Vyhodnotenie zmien úrovne rýchlostno-silových schopností medzi obdobím rokov 2013-2015 potvrdilo výkonnostný progres rozvoja explozívnej sily dolných končatín po uplynutí jedného roka. V porovnaní s hráčmi pôsobiacimi v zahraničí dosahovali hráči pôsobiaci v slovenskej lige vy̌̌šiu úroveň výkonu a výšky výskoku. To sa potvrdilo aj pri teste explozívnej sily dolných končatín bez a s protipohybom. Štatistickým spracovaním sa potvrdilo, že pri zníženej frekvencii záberov na bicyklovom ergometri stúpa úroveň výkonu v úvodnom pät'sekundovom intervale.
\end{abstract}

\begin{abstract}
Speed and strength may be referred to as a factor determining success in ice hockey. These abilities are developed mainly during the summer preparatory period. Upon its completion players underwent testing aimed to determine body composition, strength and anaerobic alactic abilities by performing the Wingate test. The reference sample consisted of 11 senior category ice hockey players playing for the hockey teams in NHL, KHL, and Czech and Slovak national leagues. The evaluation of changes in speed and strength between 2013 and 2015 showed gains in lower-body explosive power after a one-year period. Compared to players playing for hockey clubs abroad, Slovak players achieved higher level of explosive power and jump height as indicated by performances in lower-body explosive power test performed both with and without countermovement. Statistical analysis showed that power increases during the initial five-second interval at lower pedaling rate on the bicycle ergometer.
\end{abstract}

\section{Klúčové slova}

ladový hokej, tréning, silové schopnosti, rýchlostné schopnosti, seniorská kategória.

\section{Key words}

ice hockey, training, strength, speed, senior hockey players.

\section{Úvod}

Zat'aženie v l'adovom hokeji predstavuje fyzicky náročný, intervalový a prerušovaný typ pohybovej činnosti. Je charakteristický krátkymi 30 až 80 sekundovými striedaniami, spojenými s intenzívnou anaeróbnou činnostou (Burr et al., 2008). Trénovanost' pre zápasové požiadavky si v l'adovom hokeji vyžaduje približne $31 \%$ zastúpenia aeróbneho oxidatívneho a $69 \%$ anaeróbneho glykolitického energetického systému. Tieto hodnoty sa líšia $\mathrm{v}$ závislosti od úrovne sút’aže, intenzity zat'aženia, štýlu hry a hráčskej pozície (MacLean, 2015). Farlinger a Fowles (2008) pri aplikácii korelačnej 
analýzy konštatovali, že medzi výbušnou silou, zrýchlením a rýchlost'ou korčul'ovania sa nachádza signifikantná závislost'. Na základe toho je vhodné tréningový proces hokejistov dopĺn̆at' o kondičné programy determinujúcich faktorov korčuliarskej výkonnosti (Behm, Wahl, Button, Power, and Anderson, 2005; Farlinger \& Fowles, 2008). V priebehu sút’ažného obdobia dochádza u hráčov dorasteneckej a juniorskej kategórie k nárastu korčuliarskej rýchlosti, ktorej rozvoj je v prevažnej miere zastúpený tréningovou činnost'ou na l’ade. Paradoxne nedochádza k štatisticky významným zmenám v rozvoji všeobecnej pohybovej výkonnosti so zameraním na silové schopnosti. Analýza všeobecnej pohybovej výkonnosti poukazuje na skutočnost', že v priebehu sút'ažného obdobia nedochádza k rozvoju silových schopností. Tie sú podmienené realizáciou kondičných programov zameraných na determinujúce faktory korčul'ovania, medzi ktoré je možné zaradit' aj rýchlostno-silové schopnosti (Kokinda \& Turek, 2015).

\section{Metodika}

Ciel' práce je zameraný na hodnotenie zmien rýchlostno-silových schopností hokejistov po ukončení letného prípravného obdobia v priebehu trojročného časového intervalu. Členovia výskumného súboru sú súčast'ou širšieho reprezentačného výberu Slovenskej republiky. V tabul'ke 1 je uvedená základná charakteristika súboru, ktorú tvorili ôsmi útočníci, jeden obranca a dvaja brankári.

Tabulka 1: Charakteristika súboru

\begin{tabular}{|c|c|c|c|c|c|c|c|c|c|c|c|}
\hline \multirow{2}{*}{ Č. I. } & \multirow{2}{*}{$\mathbf{n}$} & \multicolumn{2}{|c|}{ Vek (roky) } & \multicolumn{2}{|c|}{$\begin{array}{c}\text { Telesná výška } \\
\text { (cm) }\end{array}$} & \multicolumn{2}{c|}{$\begin{array}{c}\text { Telesná } \\
\text { hmotnost' (kg) }\end{array}$} & \multicolumn{2}{|c|}{$\begin{array}{c}\text { Svalová hmota } \\
\text { (\%) }\end{array}$} & \multicolumn{2}{|c|}{ Tuk (\%) } \\
\cline { 3 - 12 } & & $\mathbf{x}$ & $\mathbf{5}$ & $\mathbf{x}$ & $\mathbf{s}$ & $\mathbf{x}$ & $\mathbf{s}$ & $\mathbf{x}$ & $\mathbf{s}$ & $\mathbf{x}$ & $\mathbf{s}$ \\
\hline $\mathbf{2 0 1 3}$ & 11 & 25,8 & 5,8 & 183,6 & 6,2 & 86 & 7,3 & 44 & 0,5 & 11 & 0,2 \\
\hline $\mathbf{2 0 1 4}$ & 11 & 26,8 & 5,8 & 184,3 & 5,8 & 87,9 & 6,2 & 50,7 & 1,1 & 12,9 & 2,1 \\
\hline $\mathbf{2 0 1 5}$ & 11 & 27,8 & 5,8 & 184,3 & 6,2 & 88,8 & 7,3 & 49,5 & 1,1 & 14,2 & 1,8 \\
\hline
\end{tabular}

Legenda: Č. I. - časový interval, $\mathrm{n}$ - početnost’ súborov, x - aritmetický priemer, s - smerodajná odchýlka.

Traja hokejisti pôsobili v NHL, KHL a českej extralige. Zvyšných osem členov výskumného súboru tvorili hráči aktuálneho majstra Slovenska v seniorskej kategórií, ktorí absolvovali po ukončení letnej prípravy výstupné testovanie v Diagnostickom centre Fakulty športu. Vyhodnocované boli ukazovatele telesnej kompozície analyzátorom In Body 720. Diagnostika silových schopností bola realizovaná na výskokovom ergometri FiTRO Jumper dvoma metodickými postupmi. Prvý test pozostával z opakovaných znožných vertikálnych výskokov vykonaných maximálnym úsilím s ciel'om dosiahnut' najvyššiu výšku výskoku so súčasne najkratším dotykovým kontaktom s podložkou. Dížka trvania testu bola 10 sekúnd s elimináciou pohybu paží. Druhý test bol zameraný na dosahovanie maximálneho vertikálneho výskoku bez protipohybu a s protipohybom. Analýza anaeróbnych alaktátových schopností a špeciálnej trénovanosti bola realizovaná Wingate testom. Testovanie týchto položiek bolo realizované na bicyklovom ergometri s nastavenou konštantnou brzdnou silou, ktorá sa vypočítava z telesnej hmotnosti (7,5 N.kg-1). Dížka testu bola 30 sekúnd a úlohou testovaných bolo dosiahnut' maximálny výkon počas celého časového intervalu. Súčast'ou testu bola realizácia 5-sekundového predštartu, na základe čoho bola stanovená frekvencia otáčok, ako súčast' testovacieho protokolu. Hodnotiacimi parametrami boli maximálny a priemerný výkon. Maximálny výkon sa dosahuje v prvom 5-sekundovom intervale a je odrazom anaeróbnych alaktátových schopností. Priemerný výkon z 30-sekundového zat’aženia charakterizuje úroveň anaeróbnej kapacity. Vypočítaním percentuálneho podielu poklesu výkonu od úvodného po záverečný interval dostaneme index únavy, ktorý nepriamo poukazuje na podiel aktivácie rýchlych, resp. pomalých svalových vlákien. Identický testovací protokol absolvovali aj traja hráči, ktorí sa individuálne pri- 
pravovali na blížiacu sa sezónu v zahraničných ligách. Vyhodnotenie signifikantnosti medzi obdobím rokov 2013-2015 bolo realizované Wilcoxonovým T testom na hladine štatistickej významnosti $p<0,05$. V etape spracovania výsledkov pri kvalitatívnej analýze boli použité logické metódy analýza, syntéza, indukcia, komparácia. Získané informácie sú vecne vyhodnotené a interpretované vo forme tabuliek a grafov.

\section{Výsledky}

Dlhodobé sledovanie zmien rýchlostno-silových schopností profesionálnych hokejistov je podmienené plánovaním ročných tréningových cyklov, ktoré je možné rozdelit' na prípravné a sút’ažné. Predovšetkým v prípravnom období sú tieto údaje nevyhnutné, pre optimálny výber obsahu tréningových jednotiek. Takýto postup vytváral základ pre individuálnu prípravu hráča, ktorý sa vo veku 20 rokov začal kondične pripravovat' na seniorskú sút'až NHL. V tabul'ke 2 sú uvedené výsledky Wingate testu počas troch po sebe nasledujúcich letných prípravných obdobiach.

Tabulka 2: Hodnoty Wingate testu trojročných intervalov hráča pôsobiaceho v NHL

\begin{tabular}{|c|c|c|c|c|c|c|c|c|}
\hline C.. I. & TH (kg) & $\begin{array}{c}\text { Rpm } \\
\mathbf{0 - 5 ~ s . ~}\end{array}$ & W & W/kg & $\begin{array}{c}\text { Rpm } \\
\mathbf{2 5 - 3 0 ~ s . ~}\end{array}$ & W & W/kg & $\begin{array}{c}\text { Index } \\
\text { únavy }\end{array}$ \\
\hline $\mathbf{2 0 1 3}$ & 87 & 172 & 894,86 & 10,3 & 101 & 587,54 & 6,7 & $34,34 \%$ \\
\hline $\mathbf{2 0 1 4}$ & 90 & 183 & 1007,25 & 11,2 & 101 & 648,53 & 7,2 & $35,61 \%$ \\
\hline $\mathbf{2 0 1 5}$ & 93 & 191 & 988,81 & 10,6 & 94 & 606,83 & 6,5 & $38,63 \%$ \\
\hline
\end{tabular}

Legenda: Č. I. - časový interval, TH - telesná hmotnost', Rpm - frekvencia otáčok, s - sekundy, W - výkon vo wattoch, kg - kilogram.

Na obrázku 1 sú znázornené priemerné hodnoty zaznamenané Wingate testom u hráčov, ktorí pôsobia $\mathrm{v}$ zahraničných ligách. Je možné konštatovat', že pokles výkonu (W/kg) počas 30 sekúnd predstavuje 37,5 \% index únavy. To vytvára predpoklady pre dlhšie trvajúce anaeróbne zat'aženie. Najvyšší výkon bol zaznamenaný u útočníka pôsobiaceho v českej lige 12,28 W/kg a najnižší u brankára 9,45 W/kg.

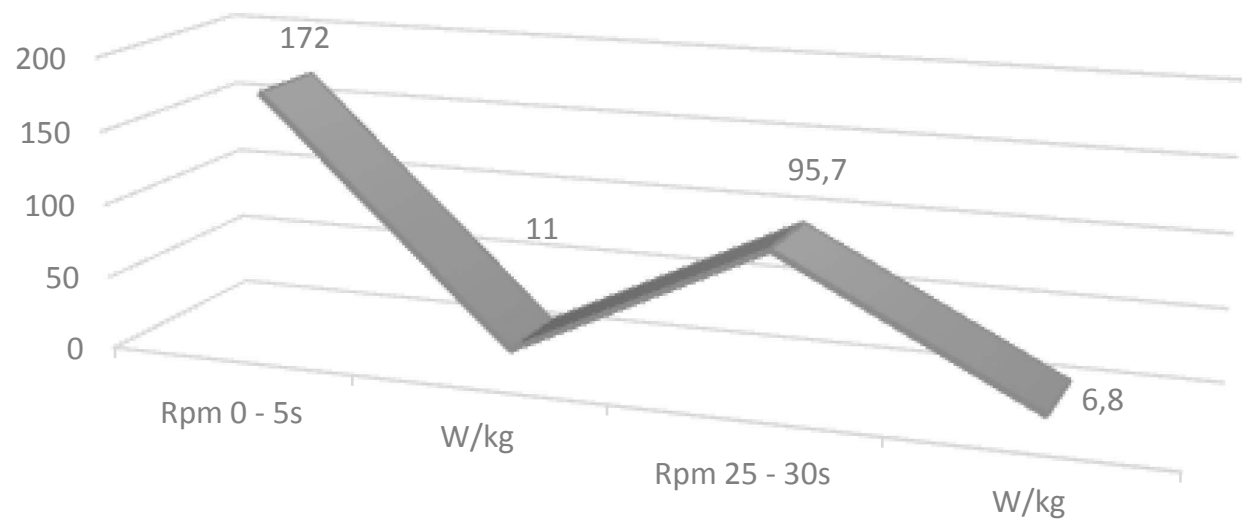

Obrázok 1: Priemerné hodnoty frekvencie otáčok a výkonu na kilogram telesnej hmotnosti hráčov pôsobiacich v zahraničných ligách $(n=3)$ 
V tabul'ke 3 sú uvedené priemerné hodnoty anaeróbneho Wingate testu v trojročnom tréningovom cykle hráčov pôsobiacich na Slovensku. Zaznamenané boli minimálne hodnoty v rozmedzí od 9,31 W/kg, po maximálne do $12,78 \mathrm{~W} / \mathrm{kg}$. Index únavy stúpal, čo naznačuje zvýšenú úroveň anaeróbneho výkonu a dynamickej rýchlostne-silovej predispozície s predpokladaným zastúpením rýchlych svalových vlákien. Pokles výkonu v závere testu nebol významný, na základe čoho je možné považovat' hodnotu indexu únavy 43,4 \% za dostatočnú, v porovnaní s ukazovatel'mi hráčov NHL, ktorých hodnoty narastali do 52 \% (Cox, Miles, Verde, and Rhodes, 1995). Pri opakovaných meraniach intraindividuálneho hodnotenia bol najvýraznejší nárast indexu únavy zaznamenaný u brankára v trojročnom období z 39,2 \% na 58,3\%.

Tabulka 3: Priemerné hodnoty Wingate testu trojročného tréningového cyklu $(\mathrm{n}=8)$

\begin{tabular}{|c|c|c|c|c|c|c|c|c|}
\hline Č. I. & TH $(\mathbf{k g})$ & $\begin{array}{c}\text { Rpm } \\
\mathbf{0 - 5} \text { s. }\end{array}$ & W & W/kg & $\begin{array}{c}\text { Rpm } \\
\mathbf{2 5 - 3 0 ~ s . ~}\end{array}$ & W & W/kg & $\begin{array}{c}\text { Index } \\
\text { únavy }\end{array}$ \\
\hline $\mathbf{2 0 1 3}$ & 85,5 & 178,4 & 884,1 & 10,3 & 91,2 & 550,1 & 6,4 & $37,7 \%$ \\
\hline $\mathbf{2 0 1 4}$ & 87,4 & 181,2 & 930,2 & 10,6 & 91,7 & 565,8 & 6,5 & $38,4 \%$ \\
\hline $\mathbf{2 0 1 5}$ & 88,4 & 168,4 & 976 & 11 & 86,6 & 543,2 & 6,1 & $43,4 \%$ \\
\hline
\end{tabular}

Legenda: Č. I. - časový interval, TH - telesná hmotnost;; Rpm - frekvencia otáčok; s - sekundy; W - výkon vo wattoch, kg - kilogram.

Zmenu úrovne absolútnych a relatívnych hodnôt maximálneho anaeróbneho výkonu je s vysokou pravdepodobnost'ou možné pripísat aj nárastu telesnej hmotnosti. V experimentálnom súbore neboli zaznamenané významné rozdiely vychádzajúce z jednotlivých postov, čo bolo zapríčinené nízkou početnost'ou obrancov a brankárov. Za hlavné kritérium podmieňujúce zmeny v úrovni rýchlostno-silových schopností je možné označit' zameranie obsahu tréningového procesu.

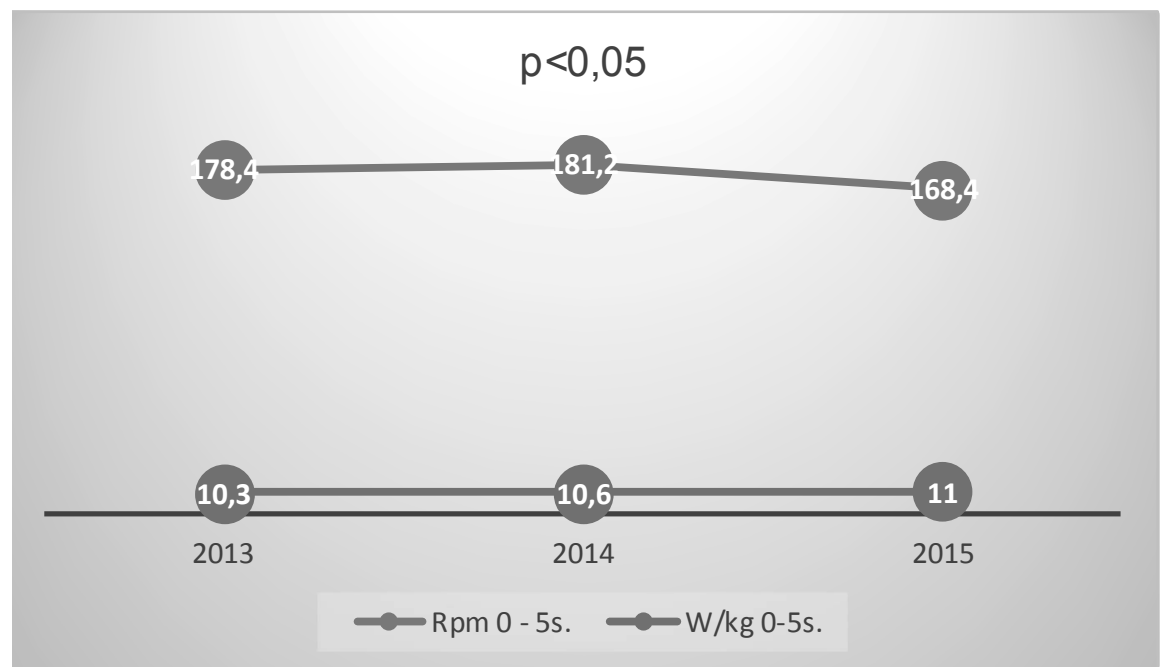

Obrázok 2: Priemerné hodnoty frekvencie otáčok a výkonu na kilogram telesnej hmotnosti hráčov pôsobiacich na Slovensku $(\mathrm{n}=8)$

Na základe štatistického spracovania je možné konštatovat', že pri zníženej frekvencii záberov stúpa výkon v úvodnom 5 sekundovom intervale (obrázok 2). Pri vyhodnocovaní ostatných ukazovatel'ov Wingate testu sa štatistická významnost' rozdielov v trojročnom sledovaní nepotvrdila (tabul'ka 4). 
Tabulka 4: Vyhodnotenie signifikantnosti premenných v období 2013-2015

\begin{tabular}{|c|c|}
\hline Premenné & $\mathbf{p}$ \\
\hline Telesná hmotnost' & 0,051 \\
\hline Výskoková ergometria h (cm) & $0,011^{*}$ \\
\hline Výskoková ergometria P (W/kg) & $0,012^{*}$ \\
\hline Frekvencia otáčok $0-5$ sekúnd & $0,011^{*}$ \\
\hline Absolútny výkon vo wattoch & 0,123 \\
\hline $\begin{array}{c}\text { Výkon vo wattoch na kilogram } \\
\text { hmotnosti }\end{array}$ & 0,326 \\
\hline Frekvencia otáčok 25-30 sekúnd & 0,093 \\
\hline Absolútny výkon vo wattoch & 0,888 \\
\hline $\begin{array}{c}\text { Výkon vo wattoch na kilogram } \\
\text { hmotnosti }\end{array}$ & 0,161 \\
\hline
\end{tabular}

Legenda: ${ }^{*} \mathrm{p}<0,05$.

Graf na obrázku 3 znázorňuje výkonnostný progres explozívnej sily dolných končatín po uplynutí jedného roka. To naznačuje na adekvátnost' obsahu tréningových podnetov hlavne v príprave mimo l'adovej plochy so zameraním na rozvoj silových schopností. Najvýraznejšie sa to prejavuje pri hodnotení vertikálneho výskoku, kde boli zaznamenané $5,6 \mathrm{~cm}$ rozdiely.

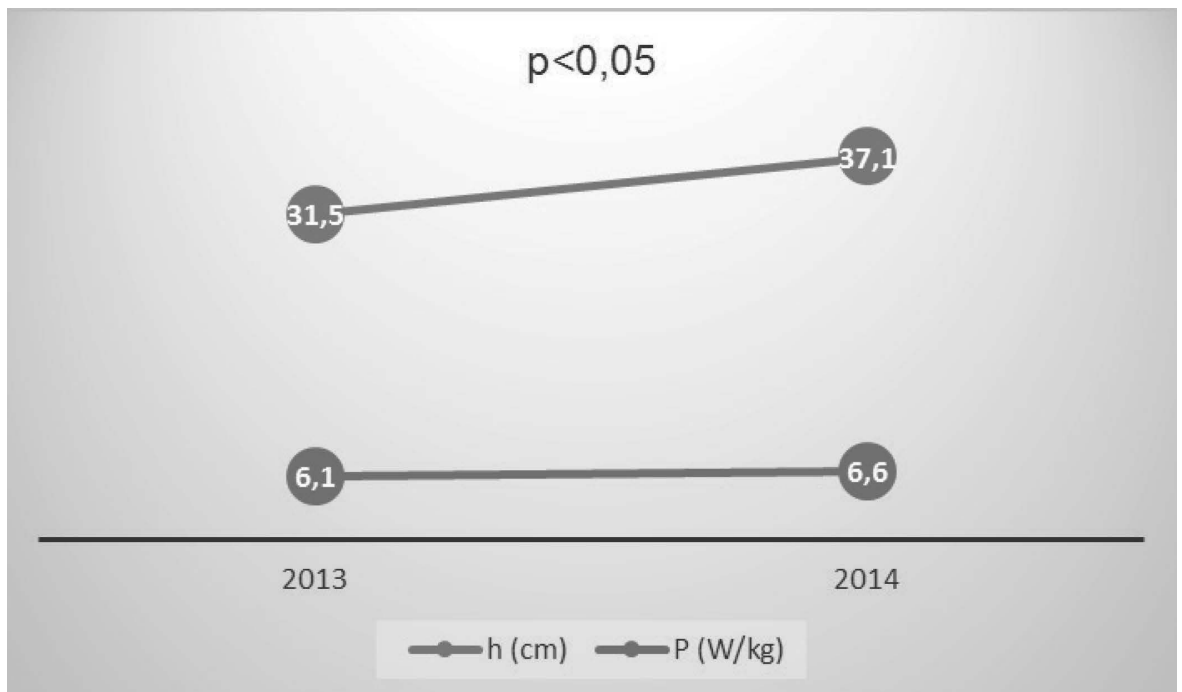

Obrázok 3: Hodnotenie úrovne explozívnej sily dolných končatín $(\mathrm{n}=8)$

V porovnaní s hodnotami na obrázku 3 hokejisti pôsobiaci v zahraničných ligách dosahovali v priemere $35,6 \mathrm{~cm}$ vertikálny výskok počas 10 sekundového časového intervalu. Priemerný výkon bol na úrovni $6,5 \mathrm{~W} / \mathrm{kg}$. 


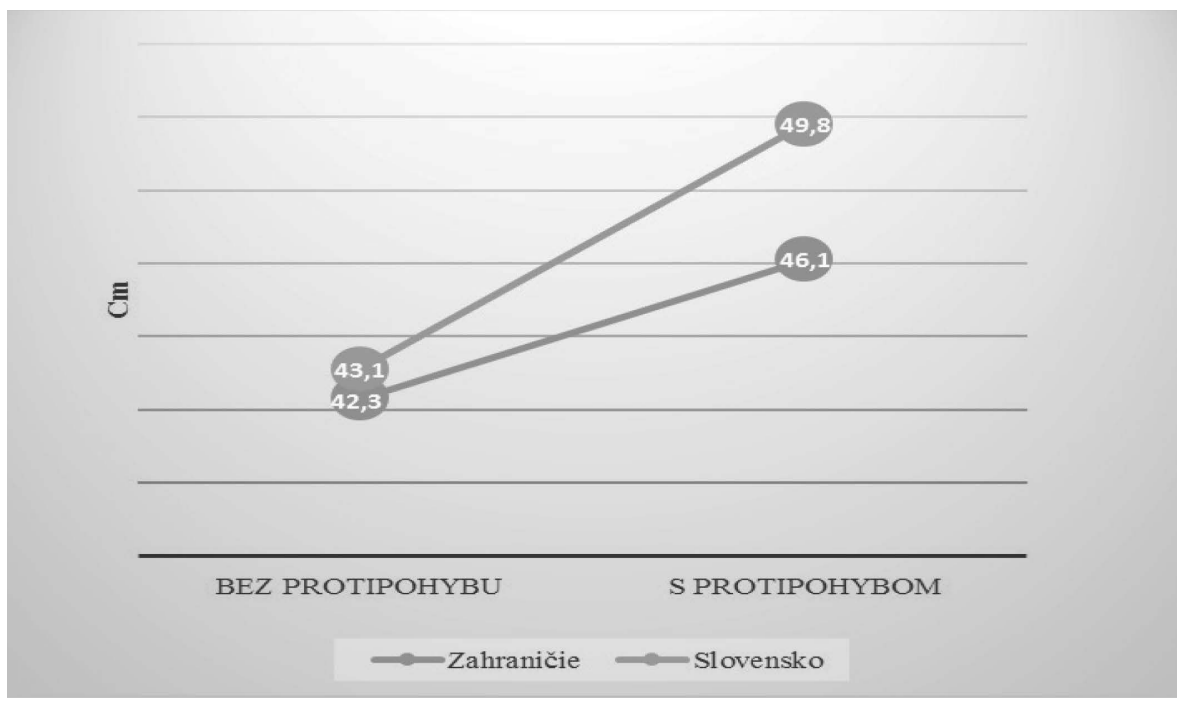

Obrázok 4: Porovnanie explozívnej sily dolných končatín bez protipohybu a s protipohybom

Determinujúcim faktorom korčuliarskej rýchlosti hokejistov je výbušná sila dolných končatín, ktorá je do značnej miery závislá od pružinového prechodu z excentrickej fázy do výbušného koncentrického prejavu. Na obrázku 4 je grafické znázornenie jednorazových maximálnych výkonov vertikálneho výskoku hráčov zaradených do výskumného súboru. Vyššiu úroveň dosahovali hráči pôsobiaci v slovenskej lige. Rozdiely vykonávania jednotlivých odrazov bez protipohybu a s protipohybom boli v rozmedzí od 3,8-6,7 cm.

\section{Diskusia}

Normatívne databázy špecializácie l'adový hokej poukazujú na rôznorodost' použitých protokolov testovania, na základe ktorých je zaznamenávaná vysoká variabilita nameraných údajov. Na základe výsledkov NHL je možné konštatovat', že obrancovia a útočníci dosahujú anaeróbnu výkonnost' na úrovni 12,3 W/kg. Nižšie hodnoty boli zaznamenané u brankárov 11,9 W/kg (Cox, et al., 1995; Rhodes, Cox, \& Quinney, 1986). U brankára, ktorý bol zaradený do výskumného súboru mala maximálna hodnota anaeróbneho výkonu v priebehu trojročného cyklu progresívny charakter v rozmedzí od 9,31-11,96 W/kg. Zaznamenané boli aj zmeny medzi obrancami a útočníkmi v úrovni absolútnych a relatívnych hodnôt anaeróbnej kapacity a anaeróbneho výkonu. Heller (1998) konštatuje $10 \%-20 \%$ vyššie hodnoty anaeróbneho výkonu a kapacity v porovnaní s hráčmi NHL v prezentovanej štúdií (Cox, et al., 1995). Burr et al. (2008) vo svojej štúdii testoval 853 hráčov od roku 1998-2006 s vekovým priemerom 18 rokov, telesnou výškou 186,2 cm a hmotnostou 87,4kg, ktorí patrili vo svojom veku medzi 120 top hráčov sveta začlenených do draftu NHL. Maximálne hodnoty výkonu vo Wingate teste dosiahli obrancovia $1000 \mathrm{~W}$, útočníci $974 \mathrm{~W}$ a napokon brankári 897 W. Index únavy bol relatívne rovnaký v celej vzorke 38,1 \%. Gledhill a Jamnik (2007) podobne uvádzajú výsledky Wingate testu u draftovaných hráčov do NHL z roku 2004 a 2005. Maximálne hodnoty výkonu $1044 \mathrm{~W}$ pre rok 2004 a $969 \mathrm{~W}$ v roku 2005, anaeróbnu výkonnost' na úrovni 12,0 W/ $\mathrm{kg}$ a $11,1 \mathrm{~W} / \mathrm{kg}$, index únavy 39,6 \% a 35,7 \%. Hráči zo slovenskej najvyššej hokejovej sútaže $(\mathrm{n}=12)$ dosiahli vyššie hodnoty oproti nami sledovaným hráčom pri výskoku bez protipohybu 43,5 cm, ale nižší výkon vo výskoku s protipohybom 47,3 cm (Pupiš, Pivovarniček, Pupišová, Tokárová, a Moravčík, 2014). V tréningovom procese športových hier je dôležité brat' do úvahy individuálne špecifiká hráčov, ktoré sa prejavujú v nameraných hodnotách (Nemec, 2013). 


\section{Závery}

Rozvoj rýchlostno-silových schopností z dlhodobého hl'adiska je možné označit' za špecifický a do značnej miery poznačený know-how daného profesionálneho klubu. Na základe čiastkových výsledkov je možné konštatovat', že rozdiely v úrovni rýchlostno-silových schopností profesionálnych hokejistov nedosahujú štatisticky významné zmeny. Kvalita tréningových postupov v kondičnej príprave klubu pôsobiaceho v slovenskej lige je porovnatel'ná so zahraničnými. Analýzou bola zaznamenaná vyššia úroveň rýchlostno-silových schopností práve u hráčov pôsobiacich v slovenskej lige. Na strane druhej, úroveň technicko-taktického majstrovstva a kvalita herných činností je priamo úmerná kvalite danej ligy. $\mathrm{V}$ trojročnom sledovaní sa ukazuje progresívny charakter rozvoja anaeróbnych predpokladov, ktoré sú do značnej miery závislé od veku. Ukazuje sa, že prechod z juniorského do seniorského hokeja je charakteristický osciláciou rýchlostno-silových schopností, ale pre kategóriu 27 ročných hokejistov, dostatočne etablovaných úrovňou ligového hokeja je progresívny.

\section{Literatúra}

Behm, G. D., Wahl, J. M., Button, C. D., Power, E. K., \& Anderson, G. K. (2005). Relationship between hockey skating speed and selected performance measures. Journal of Strength and Conditioning Research, 19(2), 326-331.

Burr, F. J., Jamnik, V., Baker, J., Macpherson, A., Gledhill, N., \& McGuire, J. E. (2008). Relationship of physical fitness test results and hockey playing potential in elite-level ice hockey players, Journal of Strength and Conditioning Research, 22(5), 1535-1543.

Cox, M. H., Miles, D. S., Verde, T. J., \& Rhodes, E. C. (1995). Applied physiology of ice hockey. Sports Medicine, 19(3), $184-201$.

Farlinger, M., \& Fowles, J. (2008). The effect of sequence of skating-specific training on skating performance. International Journal of sports Physiology and Performance, 3, 185-198.

Gledhill, N., \& Jamnik, V. (2007). Detailed assessment protocols for NHL entry draft players [online]. Toronto: York University [cit. 2016-02-24]. Dostupné z: http://metodikaikozpont.hu/edzoi/5nhl.pdf.

Heller, J. (1998). Využití anaerobní diagnostiky v ledním hokeji. Trenérské listy, 16(3), 30-31.

Kokinda, M., \& Turek, M. (2015). Výber a príprava mladých hokejistov. Prešov: PU v Prešove, Fakulta športu a HC Košice.

MacLean, E. (2015). A theoretical review of the physiological demands of ice-hockey and a full year periodized sport specific conditioning program for the canadian junior hockey player [online]. Perth: Edith Cowen University [cit. 2015-12-28]. Dostupné z: http://performancetrainingsystems.net/Resources/Hockey\%20Paper\%20-\%20Final.pdf.

Nemec, M. (2013). The use of lactate curve in the training of middle-distance runners. Scientific review of Physical Culture, 3(4), 81-86.

Pupiš, M., Pivovarniček, P., Pupišová, Z., Tokárová, M., \& Moravčík, J. (2014). Effectiveness of static and dynamic stretching prior to speed and speed-strength load. Journal of Physical Education and Sport, 14(4), 455-458.

Rhodes, E. C., Cox, M. H., \& Quinney H. A. (1986). Physiological monitoring of national hockey league regulars during the 1985-1986 season. Canadian Journal f Applied Sport Sciences, 11(3), 36.

\section{Corresponding author}

Mgr. Marek Kokinda, PhD.

Fakulta športu, Prešovská univerzita v Prešove, Prešov, Slovakia

marek.kokinda@unipo.sk 